\title{
${ }^{18}$ F-ASEM, a Radiolabeled Antagonist for Imaging the a7-Nicotinic Acetylcholine Receptor with PET
}

\author{
Andrew G. Horti ${ }^{1}$, Yongjun Gao ${ }^{1}$, Hiroto Kuwabara ${ }^{1}$, Yuchuan Wang ${ }^{1}$, Sofya Abazyann ${ }^{2,3}$, Robert P. Yasuda ${ }^{4}$, Thao Tran ${ }^{4}$, \\ Yingxian Xiao ${ }^{4}$, Niaz Sahibzada ${ }^{4}$, Daniel P. Holt ${ }^{1}$, Kenneth J. Kellar ${ }^{4}$, Mikhail V. Pletnikov ${ }^{2,3}$, Martin G. Pomper ${ }^{1}$, \\ Dean F. Wong ${ }^{1,2}$, and Robert F. Dannals ${ }^{1}$ \\ ${ }^{1}$ Department of Radiology, Johns Hopkins School of Medicine, Baltimore, Maryland; ${ }^{2}$ Department of Neuroscience, Johns Hopkins \\ School of Medicine, Baltimore, Maryland; ${ }^{3}$ Department of Molecular and Comparative Pathobiology, Johns Hopkins School of \\ Medicine, Baltimore, Maryland; and ${ }^{4}$ Georgetown University, Washington, District of Columbia
}

The a7-nicotinic cholinergic receptor ( $\mathrm{a} 7-\mathrm{nAChR})$ is a key mediator of brain communication and has been implicated in a wide variety of central nervous system disorders. None of the currently available PET radioligands for $\mathrm{a} 7-\mathrm{nAChR}$ are suitable for quantitative PET imaging, mostly because of insufficient specific binding. The goal of this study was to evaluate the potential of ${ }^{18} \mathrm{~F}-\mathrm{ASEM}$ (18 F-JHU82132) as an a7-nAChR radioligand for PET. Methods: The inhibition binding assay and receptor functional properties of ASEM were assessed in vitro. The brain regional distribution of ${ }^{18} \mathrm{~F}-\mathrm{ASEM}$ in baseline and blockade were evaluated in DISC1 mice (dissection) and baboons (PET). Results: ASEM is an antagonist for the a7-nAChR with high binding affinity $\left(\mathrm{K}_{\mathrm{i}}=0.3 \mathrm{nM}\right) .{ }^{18} \mathrm{~F}-\mathrm{ASEM}$ readily entered the baboon brain and specifically labeled a7-nAChR. The in vivo specific binding of ${ }^{18} \mathrm{~F}$-ASEM in the brain regions enriched with a7-nAChRs was 80\%-90\%. SSR180711, an a7-nAChR-selective partial agonist, blocked ${ }^{18} \mathrm{~F}$-ASEM binding in the baboon brain in a dose-dependent manner, suggesting that the binding of ${ }^{18} \mathrm{~F}$-ASEM was mediated by a7-nAChRs and the radioligand was suitable for drug evaluation studies. In the baboon baseline studies, the brain regional volume of distribution $\left(\mathrm{V}_{\mathrm{T}}\right)$ values for ${ }^{18} \mathrm{~F}$-ASEM were 23 (thalamus), 22 (insula), 18 (hippocampus), and 14 (cerebellum), whereas in the binding selectivity (blockade) scan, all regional $\mathrm{V}_{\mathrm{T}}$ values were reduced to less than 4 . The range of regional binding potential values in the baboon brain was from 3.9 to 6.6. In vivo cerebral binding of ${ }^{18} \mathrm{~F}$ ASEM and a7-nAChR expression in mutant DISC1 mice, a rodent model of schizophrenia, was significantly lower than in control animals, which is in agreement with previous postmortem human data. Conclusion: ${ }^{18} \mathrm{~F}$-ASEM holds promise as a radiotracer with suitable imaging properties for quantification of $\alpha 7-n A C h R$ in the human brain.

Key Words: a7-nAChR; nicotine; PET; baboon; ${ }^{18} \mathrm{~F}-\mathrm{ASEM}$

J Nucl Med 2014; 55:672-677

DOI: 10.2967/jnumed.113.132068

$\mathbf{N}$ icotinic cholinergic receptors (nAChRs) are ionotropic cationic channels that are fundamental to physiology and, as a class, represent an important target for drug discovery. nAChRs are found

Received Sep. 3, 2013; revision accepted Dec. 2, 2013.

For correspondence or reprints contact: Andrew G. Horti, PET Center, Division of Nuclear Medicine, Department of Radiology, Johns Hopkins School of Medicine, 600 North Wolfe St., Nelson B1-122, Baltimore, MD 21287-0816.

E-mail: ahorti1@jhmi.edu

Published online Feb. 20, 2014.

COPYRIGHT (c) 2014 by the Society of Nuclear Medicine and Molecular Imaging, Inc. in the central nervous system (CNS), autonomic and sensory ganglia, and various nonneuronal cells. In the CNS, nAChRs mediate fast excitatory postsynaptic responses to its cognate ligand acetylcholine and other nicotinic agonists (1).

Cerebral nAChRs are composed of various $\alpha$ and $\beta$ subunits that can assemble into pentamers, with $\alpha 4 \beta 2$-nAChR and $\alpha 7-n A C h R$ subtypes representing the highest concentration of nAChRs in the CNS (2). The $\alpha 7-n A C h R$ is involved in pathogenesis of a variety of disorders and conditions including schizophrenia and Alzheimer disease, inflammation and traumatic brain injury, cancer, and macrophage chemotaxis $(3-8)$.

Despite intense study, the role of $\alpha 7$-nAChRs in the brain is not fully understood. PET is the most advanced technique to map and quantify cerebral receptors and their occupancy by neurotransmitters and drugs in human subjects. The lack of PET radioligands for quantitative imaging of the $\alpha 7$-nAChRs in human subjects represents a gap that hampers research of this receptor system and development of new drugs for this target.

Over the past decade, considerable effort has been expended toward the development of $\alpha 7$-nAChR ligands, and more than 20 compounds have been radiolabeled for PET and SPECT, but previous efforts by several research groups (9-11), including our own (12-14), to develop a clinically viable $\alpha 7-\mathrm{nAChR}$ tracer for PET or SPECT have proved unsuccessful. None of these radioligands manifested sufficiently high specific binding at $\alpha 7-n A C h R s$ in vivo. Even ${ }^{11} \mathrm{C}$-CHIBA-1001, the recent PET radioligand for human subjects, exhibited a low $\alpha 7$-nAChR binding affinity and poor in vivo selectivity $(15,16)$. Accordingly, there is still a pressing scientific need for a practical PET radiotracer for quantification of $\alpha 7$-nAChRs.

As part of our PET radioligand development program, we developed ${ }^{18} \mathrm{~F}$-ASEM $\left({ }^{18} \mathrm{~F}\right.$-JHU82132, 3-(1,4-diazabicyclo[3.2.2] nonan-4-yl)-6-[ $\left.{ }^{18} \mathrm{~F}\right]$ fluorodibenzo[ $\left.b, d\right]$ thiophene 5,5 -dioxide), an ${ }^{18} \mathrm{~F}$-labeled, high-affinity and -selectivity $\alpha 7-\mathrm{nAChR}$ PET radioligand (Fig. 1) that showed excellent specific binding $\left(\mathrm{BP}_{\mathrm{ND}}=8\right)$ in control CD-1 mice (17). Here, we describe further preclinical characterization of ${ }^{18} \mathrm{~F}$-ASEM in vitro and in vivo in baboon PET imaging studies and in DISC1 mice, a rodent model of schizophrenia.

\section{MATERIALS AND METHODS}

All experimental animal protocols were approved by the Animal Care and Use Committee of the Johns Hopkins Medical Institutions.

${ }^{18} \mathrm{~F}$-ASEM and unlabeled ASEM were synthesized as described by our laboratory (17). Briefly, the radiotracer was prepared by nucleophilic 


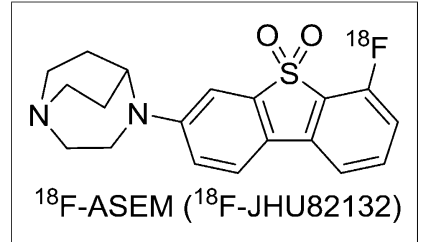

FIGURE 1. Chemical structure of high-binding-affinity a7-nAChRselective PET radioligand ${ }^{18} \mathrm{~F}$ ASEM (18F-JHU82132) (17). $7 \%(n=12)$.

\section{In Vitro Inhibition Binding Assay of ASEM and Functional Electrophysiology Method}

HEK293 cell culture and stable transfections of $\alpha 7-\mathrm{nAChR}$ and the ASEM inhibition binding assay with ${ }^{125} \mathrm{I}-\alpha$-bungarotoxin were performed as described previously (supplemental data; supplemental materials are available at http://jnm.snmjournals.org) (18).

Whole-cell voltage clamp (holding potential, $-70 \mathrm{mV}$ ) recordings from HEK293 cells stably transfecting the rat $\alpha 7-n A C h R$ were made with patch electrodes (5-6 M $\Omega$ ) containing a solution ( $\mathrm{pH}$ 7.2) composed of potassium gluconate $(145 \mathrm{mM})$, ethylene glycol tetraacetic acid (5 mM), $\mathrm{MgCl}_{2}$ (2.5 mM), 4-(2-hydroxyethyl)-1-piperazineethanesulfonic acid (HEPES) $(10 \mathrm{mM})$, adenosine triphosphate sodium (ATP.Na) $(5 \mathrm{mM})$, and guanosine triphosphate sodium (GTP.Na) $(0.2 \mathrm{mM})$. Cells were continuously perfused with recording solution with the following composition: $\mathrm{NaCl}(130 \mathrm{mM}), \mathrm{KCl}(5 \mathrm{mM}), \mathrm{CaCl}_{2}$ (2 $\mathrm{mM}), \mathrm{MgCl}_{2}(2 \mathrm{mM})$, glucose $(10 \mathrm{mM})$, and HEPES (10 mM), $\mathrm{pH}$ 7.4 , at a temperature of $24^{\circ} \mathrm{C}$. The patch pipette was coupled to an amplifier (Axopatch 200B; Molecular Devices) and its signal filtered (5 kHz), digitized with a Digidata 1440A (Molecular Devices), and analyzed with pClamp 10 software (Molecular Devices). Acetylcholine was delivered to the cells rapidly by pressure application (picospritzer; World Precision Instruments) for $0.5 \mathrm{~s}$. A bath was applied to the compound ASEM for 2 min before and during the application of acetylcholine by pressure application.

\section{Biodistribution Study in Mutant DISC1 and Control Mice}

Male DISC1 (16-18 g) and control (17-19 g) mice both on a C57BL/6 background were generated as previously described (19) and were used for biodistribution studies, with 6 animals per data point. The animals were sacrificed by cervical dislocation at $90 \mathrm{~min}$ after injection of ${ }^{18} \mathrm{~F}$-ASEM (2.6 MBq; specific radioactivity, $\sim 300$ $\mathrm{GBq} / \mu \mathrm{mol}$, in $0.2 \mathrm{~mL}$ of saline) into a lateral tail vein. The brains were rapidly removed and dissected on ice. The brain regions of interest were weighed, and their radioactivity content was determined in an automated $\gamma$ counter with a counting error below 3\%. Aliquots of the injectate were prepared as standards, and their radioactivity content was determined along with the tissue samples. The percentage injected dose per gram of tissue (\% ID/g tissue) was calculated.

\section{Western Blot with DISC1 and Control Mice}

Mice were euthanized at postnatal day 21 to evaluate the expression of $\alpha 7-n A C h R$ in mutant DISC1 and control animals. Frontal cortices were quickly dissected out on ice-cold phosphate-buffered saline and frozen on dry ice and kept at $-80^{\circ} \mathrm{C}$ until used. These samples were assayed for expression of mutant DISC1 (19). Membranes were incubated overnight at $4{ }^{\circ} \mathrm{C}$ with either mouse anti-myc antibody (Santa Cruz Biotechnology Inc.; 1:1,000) to assess the expression of mutant DISC1 tagged with myc or rabbit polyclonal antibody to $\alpha 7-\mathrm{nAChR}$ (ab10096 [Abcam Inc.]; 1:500). Secondary antibodies were peroxidase-conjugated goat antimouse (Kierkegaard Perry Labs; 1:1,000) or sheep antirabbit (GE Healthcare; 1:2,500). The optical density of protein bands on each digitized image was normalized to the optical density of $\beta$-tubulin as a loading control (Cell Signaling Technology Inc; 1:10,000). Normalized values were used for statistical analyses.

\section{Baboon PET Imaging and Baboon PET Data Analysis}

PET experiments were performed on 3 male baboons (Papio anubis; weight, 20.1-26 kg) on the High Resolution Research Tomograph (CPS Innovations, Inc.). The animals were anesthetized and handled as described previously (supplemental data) (20). Three animals were scanned with ${ }^{18} \mathrm{~F}$-ASEM in baseline scans. Dynamic PET images were acquired in a 3-dimensional list-mode for 90 min after an intravenous bolus injection of ${ }^{18} \mathrm{~F}-\mathrm{ASEM}(246-319 \mathrm{MBq} ; n=3)$, with specific radioactivities in the range of $343-1,764 \mathrm{GBq} / \mu$ mol. PET images were reconstructed as described in the supplemental data.

In 2 blocking scans, the blocker SSR180711 solution in saline was given as intravenous bolus doses $(0.5$ or $5 \mathrm{mg} / \mathrm{kg}) 90 \mathrm{~min}$ before the radioligand ${ }^{18} \mathrm{~F}$-ASEM injection (doses, 147 and $251 \mathrm{MBq}$; specific radioactivity, 462 and $1,014 \mathrm{GBq} / \mu \mathrm{mol}$ ). The blocking scans were obtained for 1 of the baboons that were used in the baseline scans and separated at least $32 \mathrm{~d}$ from each other and the baseline scan.

A locally developed volume-of-interest (VOI) template was transferred to each animal's MR image using spatial normalization parameters given by SPM5 (statistical parametric mapping (21); available at http://www.fil.ion.ucl.ac.uk/spm/software/spm5) and adjusted for anatomic details. Then, VOIs were transferred to the PET spaces of the baseline and blocking scans using the MR imaging-to-PET coregistration module of SPM5 (22). Time-radioactivity curves (time-activity curves) of regions were obtained by applying the VOIs on PET frames.

One- and 2-tissue-compartmental models (TTCM) were used for derivation of regional distribution volume $\left(\mathrm{V}_{\mathrm{T}}\right)$ for ${ }^{18} \mathrm{~F}-\mathrm{ASEM}$, with and without setting the $K_{1}-k_{2}$ ratio to the estimate of a large region (denoted as TTCM-C). Akaike information criteria (23) and the numbers of outliers were used to identify the optimal plasma input method for the radioligand. In addition, the plasma reference graphical analysis (PRGA) was evaluated (24). In blocking scans, occupancies of $\alpha 7$-nAChRs by SSR 180711 were obtained as follows: occupancy $=\Delta \mathrm{V}_{\mathrm{T}} /\left(\mathrm{V}_{\mathrm{T}}\right.$ [baseline $\left.]-\mathrm{V}_{\mathrm{ND}}\right)$, where $\Delta \mathrm{V}_{\mathrm{T}}$ was given by $\mathrm{V}_{\mathrm{T}}$ (baseline) $-\mathrm{V}_{\mathrm{T}}$ (blocking), and $\mathrm{V}_{\mathrm{ND}}$, the distribution volume of nondisplaceable radioligand, was obtained as the $x$-intercept of the Lassen plot (25) of $\Delta \mathrm{V}_{\mathrm{T}}(=y)$ versus baseline $\mathrm{V}_{\mathrm{T}}$.

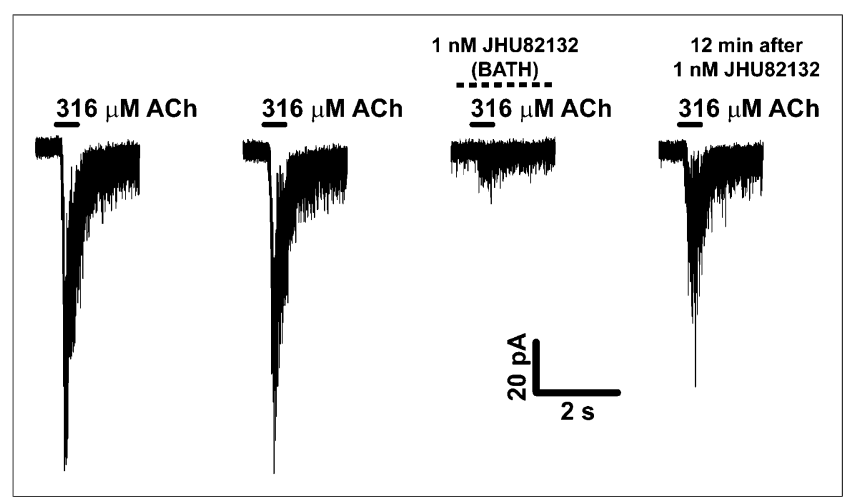

FIGURE 2. Unlabeled compound ASEM (JHU82132) inhibits activation of acetylcholine-stimulated rat a7-nAChRs. Whole-cell voltage clamp current activated with $316 \mu \mathrm{M}$ acetylcholine either before or during bath application of $1 \mathrm{nM}$ ASEM was determined in HEK293 cells stably transfected with rat a7-nAChRs. Bath application of ASEM for 2 min before and during application of acetylcholine inhibited subsequent acetylcholine-induced whole-cell current. This current was restored to $60 \%$ of baseline after $12 \mathrm{~min}$ of washing. ACh = acetylcholine. 


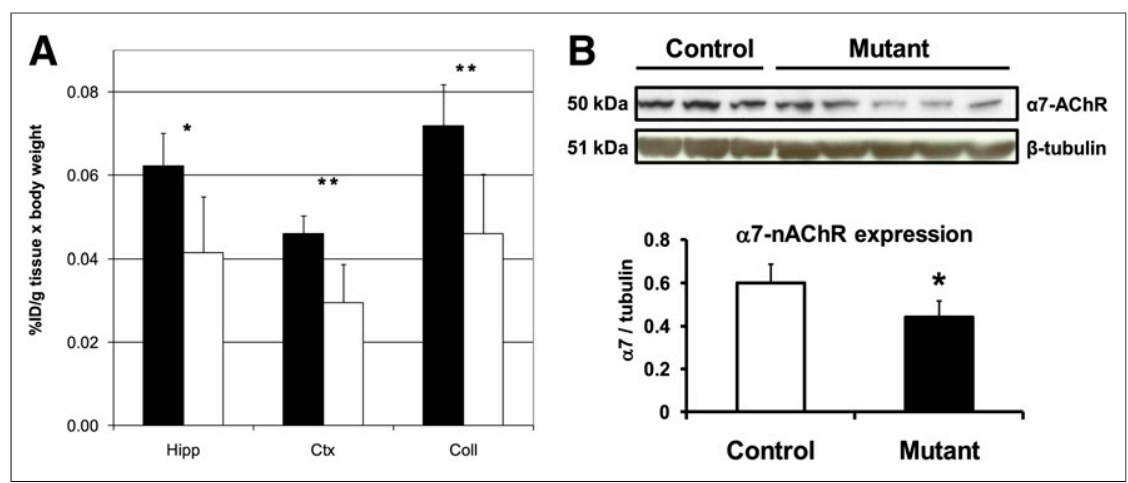

FIGURE 3. (A) Comparison of regional uptake of ${ }^{18} \mathrm{~F}$-ASEM in control (black bars) and DISC1 (white bars) mice at $90 \mathrm{~min}$ after injection. There was significant reduction of ${ }^{18} \mathrm{~F}$-ASEM in DISC1 in brain regions studied. Data are mean \%ID/g tissue $\times$ body weight \pm SD $(n=6) .{ }^{*} P=0.01$ and ${ }^{\star \star} P<0.01$, significantly different from controls (ANOVA). (B) Western blot. Expression of a7$\mathrm{nAChR}$ protein in $\mathrm{P} 21$ cortex of mutant DISC1 $(n=5)$ is significantly lower than in that of control mice $(n=3)$. ${ }^{\star} P=0.035$ (Student $t$ test, $\mathrm{t}=2.7$ ). Coll $=$ superior and inferior colliculus; Ctx $=$ cortex; Hipp $=$ hippocampus.

\section{F-ASEM: Radiometabolite Analysis in Baboon and Mice}

Baboon arterial blood samples were withdrawn at 5, 10, 20, 30, 60, and 90 min after ${ }^{18} \mathrm{~F}$-ASEM injection, and plasma was analyzed by HPLC. Male CD-1 mice (25-26 g) were injected via the lateral tail veins with $37 \mathrm{MBq}$ of high-specific-activity ${ }^{18} \mathrm{~F}$-ASEM. The mice were killed by cervical dislocation at 2 and $30 \mathrm{~min}$ after injection, and a terminal blood sample was obtained. The mouse brains were rapidly removed and analyzed by HPLC (supplemental data).

\section{RESULTS}

\section{Binding Affinity}

In 2 experiments, unlabeled ASEM exhibited high in vitro binding affinity to HEK293 cells stably transfected with rat $\alpha 7-n A C h R$ $\left(K_{\mathrm{i}}=0.3,0.3 \mathrm{nM}\right)\left({ }^{125} \mathrm{I}-\alpha\right.$-bungarotoxin $)$.

\section{In Vitro Functional Assay}

The functional activity of unlabeled ASEM was examined using whole-cell voltage clamp measurements in HEK293 cells expressing $\alpha 7$-nAChRs. As shown in Figure 2, acetylcholine at a concentration of $316 \mu \mathrm{M}$ activates these receptors, and ASEM at a concentration of $1 \mathrm{nM}$ nearly completely blocked activation by acetylcholine. Moreover, a partial block persists during the short period of washing, probably because of the high affinity of ASEM.

\section{Brain Distribution of ${ }^{18} \mathrm{~F}-\mathrm{ASEM}$ in Mutant DISC1 and Control Mice}

Mutant DISC1 mice provide a model for brain and behavioral phenotypes seen in schizophrenia (19). The comparison of regional brain uptake of ${ }^{18} \mathrm{~F}$-ASEM in mutant DISC1 versus control mice demonstrated that the uptake in the mutant mice was significantly lower in all regions studied. Because of the difference in the mouse weight (up to $15 \%$ ), the uptake values were corrected for the body weight (\%ID/g tissue $\times$ body weight) (Fig. 3A).

Western blot analysis of the expression of $\alpha 7-n A C h R$ in the cortical regions was in agreement with the biodistribution of ${ }^{18} \mathrm{~F}$-ASEM. We found a significant decrease in the levels of the receptor in the cortex of mutant DISC1 mice, compared with control mice (Fig. 3B).

\section{PET Imaging in Papio Anubis Baboons}

Heterogeneous uptake of radioactivity into the baboon brain was observed in baseline experiments after bolus injection of ${ }^{18} \mathrm{~F}$-ASEM in 3 baboons (Figs. 4 and 5). The highest accumulation of radioactivity occurred in the thalamus, insula, and anterior cingulate cortex. The intermediate uptake was observed in the putamen, hippocampus, and several cortical regions. The lowest uptake was in the corpus callosum, pons, and cerebellum. The time-activity curves of the cerebellum peaked before $20 \mathrm{~min}$ and decreased rapidly, whereas time-activity curves of other regions were slower with wider peaks and decreased relatively slowly (Fig. 4). In the 3 baseline experiments, no blocking effect was observed due to the variation of ${ }^{18} \mathrm{~F}$-ASEM specific activity from high (343 $\mathrm{GBq} / \mu \mathrm{mol})$ to very high $(1,764 \mathrm{GBq} / \mu \mathrm{mol})$.

The kinetics of ${ }^{18} \mathrm{~F}$-ASEM in the brain fitted well to a TTCM. The PRGA plots reached an asymptote (the coefficient of determination, $\left.R^{2}>0.995\right)$ at $30 \mathrm{~min}$ in all regions. Therefore, PRGA was used for further analyses. Regional values of $\mathrm{V}_{\mathrm{T}}$ of ${ }^{18} \mathrm{~F}$-ASEM in baboon are shown in Figure 6 . The thalamus, insula, and anterior cingulate cortex provided the highest $\mathrm{V}_{\mathrm{T}}$ values, and the pons, corpus callosum, and cerebellum showed the lowest $\mathrm{V}_{\mathrm{T}}$ values.

Injection of SSR180771, a selective $\alpha 7-\mathrm{nAChR}$ partial agonist $\left(K_{\mathrm{i}}=22 \mathrm{nM}\right)(26)$, reduced the regional uptake of ${ }^{18} \mathrm{~F}-\mathrm{ASEM}$ in the baboon brain in a dose-dependent manner (Fig. 7). Regional $\mathrm{V}_{\mathrm{T}}$ values in baseline and blockade experiments are shown in Figure 6.

Lassen plots showed a linear arrangement for 0.5 and $5 \mathrm{mg} / \mathrm{kg}$ doses, as exemplified for the dose of $5 \mathrm{mg} / \mathrm{kg}$ in Figure $6 \mathrm{~A}$ (for a dose of $0.5 \mathrm{mg} / \mathrm{kg}, \Delta \mathrm{V}_{\mathrm{T}}=0.39 \cdot \mathrm{V}_{\mathrm{T}}-2.1 ; R^{2}=0.643 ; \mathrm{V}_{\mathrm{ND}}=5.4$ $\mathrm{mL} / \mathrm{mL}$ ). Mean occupancy values increased from $38 \%$ with a dose

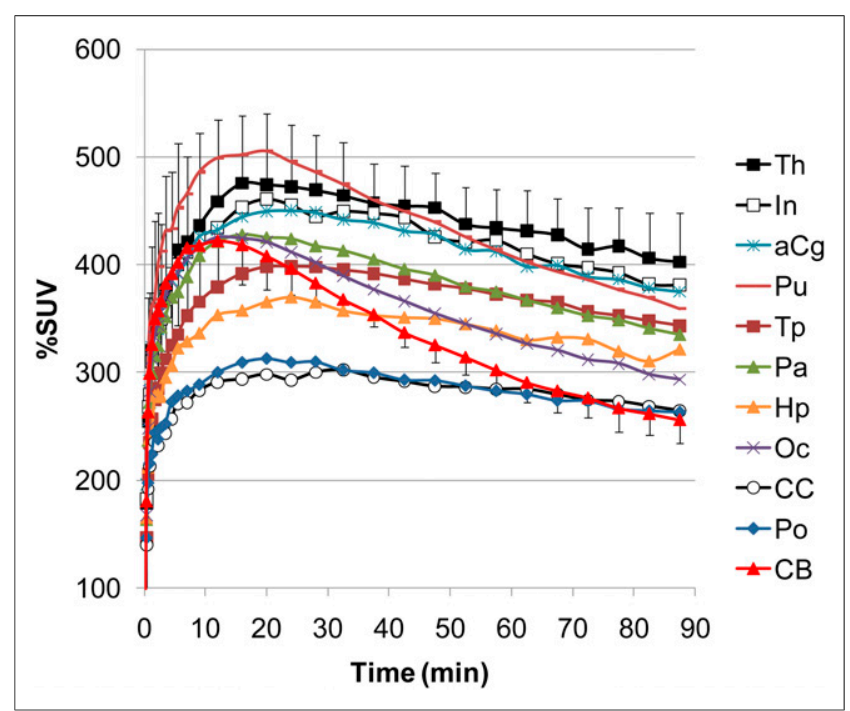

FIGURE 4. Baseline cerebral time-activity curves after bolus administration of ${ }^{18} \mathrm{~F}-\mathrm{ASEM}$ in 3 baboons. Graph demonstrates substantial heterogeneous brain uptake of ${ }^{18} \mathrm{~F}$-ASEM that matches distribution of a7-nAChR in nonhuman primates $(29,30,32)$ and reversible brain kinetics. Data are mean SUV (\%SUV) $\pm \mathrm{SD}(n=3)$. $\mathrm{aCg}=$ anterior cingulate cortex; $\mathrm{CB}=$ cerebellum; $\mathrm{CC}=$ corpus callosum; $\mathrm{Hp}=$ hippocampus; In = insula; Oc $=$ occipital lobe; $\mathrm{Pa}=$ parietal lobe; $\mathrm{Po}=$ pons; $\mathrm{Pu}=$ putamen; $T h=$ thalamus; $T p=$ temporal lobe. 


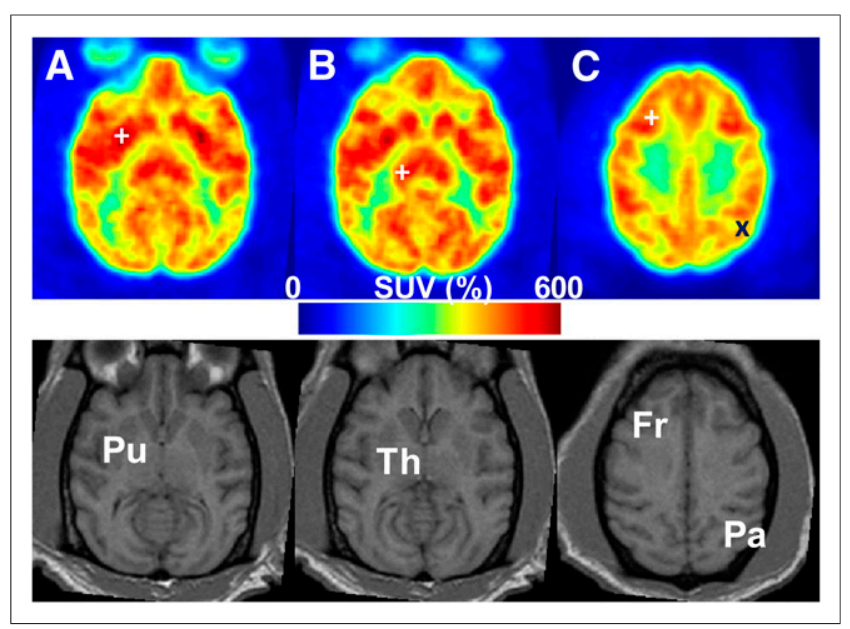

FIGURE 5. Averaged transaxial \%SUV PET images (10-90 min) of ${ }^{18} \mathrm{~F}-$ ASEM (upper) at levels showing putamen $(\mathrm{Pu} /+)$, thalamus $(\mathrm{Th} /+)$, and cortices such as frontal $(\mathrm{Fr} /+)$ and parietal $(\mathrm{Pa} / \mathrm{x})$, as shown on MR images (lower). SUV $=$ standardized uptake value.

of $0.5 \mathrm{mg} / \mathrm{kg}$ to $80.5 \%$ with a dose of $5 \mathrm{mg} / \mathrm{kg}$ using individual $\mathrm{V}_{\mathrm{ND}}$ values, and from $32.9 \%$ to $94.1 \%$ using the mean $V_{N D}$ value of 2 doses. Although estimates of $\mathrm{V}_{\mathrm{ND}}$ differed between 2 blocking scans, individual values were severalfolds lower than the lowest observed $\mathrm{V}_{\mathrm{T}}(14 \mathrm{~mL} / \mathrm{mL}$ in the pons) among the tested regions. This finding confirmed the lack of $\alpha 7-\mathrm{nAChR}$-free regions in the baboon brain and low nonspecific binding of ${ }^{18} \mathrm{~F}$-ASEM across regions (e.g., less than $30 \%$ in the pons and cerebellum and lower in other regions) and explained consistent occupancy estimates. Regional $\mathrm{BP}_{\mathrm{ND}}\left(\left[\mathrm{V}_{\mathrm{T}} / \mathrm{V}_{\mathrm{ND}}\right]-1\right)$ values of ${ }^{18} \mathrm{~F}-\mathrm{ASEM}$ in the baboon brain ranged from 3.9 to 6.6 (unitless), using the mean $\mathrm{V}_{\mathrm{ND}}$ value of the 2 blocking scans.

\section{Metabolism of ${ }^{18} \mathrm{~F}$-ASEM in Mouse and Baboon}

Radiometabolite analysis of blood samples from CD-1 mice and baboons by reversed-phase HPLC showed that the parent compound ${ }^{18} \mathrm{~F}$-ASEM was metabolized to 2 major hydrophilic species. The combined radiometabolites in the plasma reached values of
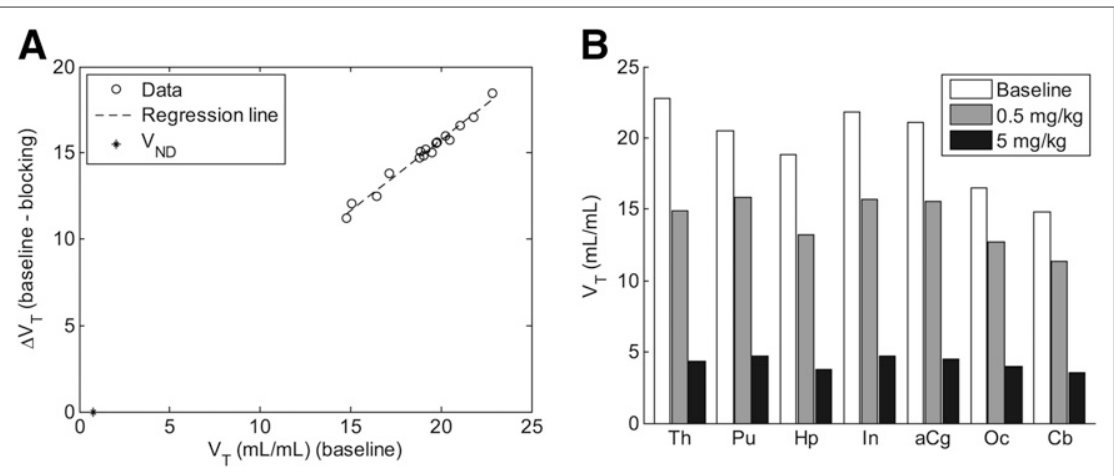

FIGURE 6. (A) Lassen plot for dose experiment of $5 \mathrm{mg} / \mathrm{kg}$ demonstrates that specific binding of ${ }^{18} \mathrm{~F}$-ASEM is blocked by a7-nAChR-selective ligand SSR180711. Data points showed linear appearance $\left(\Delta \mathrm{V}_{\mathrm{T}}=0.82 \cdot \mathrm{V}_{\mathrm{T}}-0.66 ; R^{2}=0.979 ; \mathrm{V}_{\mathrm{ND}}=0.8 \mathrm{~mL} / \mathrm{mL}\right)$. $\mathrm{V}_{\mathrm{ND}}$ is given as $x$-intercept in plot. (B) Histogram of $V_{T}$ values of ${ }^{18} \mathrm{~F}$-ASEM (PRGA) in selected brain regions of 1 baboon at baseline and after administration of 2 different doses of SSR180711. Graph demonstrates that regional binding of ${ }^{18} \mathrm{~F}$-ASEM is specific and high and mediated by a7-nAChR. aCg $=$ anterior cingulate cortex; $\mathrm{Cb}=$ cerebellum; $\mathrm{CC}=$ corpus callosum; $\mathrm{Hp}=$ hippocampus; In = insula; $\mathrm{Oc}$ = occipital lobe; $\mathrm{Pa}=$ parietal lobe; $\mathrm{Po}=$ pons; $\mathrm{Pu}=$ putamen; $\mathrm{Th}=$ thalamus.
$70 \%$ in baboons and approximately $99 \%$ in mice at 90 and $30 \mathrm{~min}$ after injection, respectively (supplemental data; Supplemental Fig. 1). These radiometabolites do not enter the brain to an appreciable extent, because at least $95 \%$ of the unchanged parent ${ }^{18} \mathrm{~F}$-ASEM was present in the mouse brain versus approximately $1 \%$ in the mouse blood after intravenous administration of ${ }^{18} \mathrm{~F}$-ASEM. The amount of unchanged parent ${ }^{18} \mathrm{~F}$-ASEM in the baboon brain should be even greater than that in mouse $(>95 \%)$ because the metabolism in baboon is slower. This observation suggests that modeling of the metabolites may not be necessary for quantification of $\alpha 7-n A C h R$ with ${ }^{18} \mathrm{~F}$-ASEM.

\section{DISCUSSION}

Our previous in vitro binding assay studies demonstrated that ASEM exhibits high $\alpha 7$-nAChR binding affinity in rat brain membranes and excellent selectivity versus other heteromeric nAChR subtypes and 5-HT $\mathrm{HT}_{3}$ (17). Those studies demonstrated that ASEM exhibits at least an order of magnitude greater binding affinity than previous $\alpha 7$-nAChR PET radioligands (17). In this report, we have confirmed the high $\alpha 7-n A C h R$ binding affinity of ASEM in the binding assay with the HEK293 cell line expressing rat $\alpha 7-n A C h R$ $\left(\mathrm{K}_{\mathrm{i}}=0.3 \mathrm{nM}\right)$.

The functional assay demonstrated that ASEM is a powerful antagonist of $\alpha 7$-nAChR (Fig. 2), which is in accord with functional properties of des-fluoro-ASEM, 3-(1,4-diazabicyclo[3.2.2] nonan-4-yl)dibenzo[b,d]thiophene 5,5-dioxide, which was recently published by Abbott Labs (27). This functional property may also be advantageous from the standpoint of safety if ${ }^{18} \mathrm{~F}$ ASEM is used in human PET studies because it should not cause toxic effects that are common among nicotinic agonists (28).

The initial in vivo distribution studies in control mice have demonstrated that ${ }^{18} \mathrm{~F}$-ASEM selectively labels $\alpha 7-n A C h R$ with very high specificity $\left(\mathrm{BP}_{\mathrm{ND}}=8\right)(17)$. On the basis of the favorable imaging properties identified in normal mice, we investigated ${ }^{18} \mathrm{~F}$-ASEM cerebral binding in mutant DISC1 mice, a rodent model of schizophrenia (19). Previous postmortem research demonstrated significantly lower densities of $\alpha 7-n A C h R$ in the cortical and subcortical (hippocampus) brain regions of schizophrenic subjects versus controls (8). In agreement with this in vitro human data, the brain regional distribution experiments with DISC1 mice showed a significant reduction of ${ }^{18} \mathrm{~F}$-ASEM binding in the $\alpha 7$-nAChR-rich colliculus, cortex, and hippocampus in comparison with control animals (Fig. 3A). Western blot data (Fig. 3B) of $\alpha 7-n A C h R$ protein expression in the cortex of DISC1 and control animals was in agreement with ${ }^{18} \mathrm{~F}$-ASEM binding.

This result in DISC1 mice is consistent with previous postmortem brain studies of subjects with schizophrenia (8) and further emphasizes the potential utility of this new radioligand for imaging $\alpha 7-\mathrm{nAChR}$ in disease.

${ }^{18}$ F-ASEM exhibited high (500\% standardized uptake value [SUV]) and reversible brain uptake in baboon brain experiments (Figs. 4 and 5). The cerebral $\alpha 7-n A C h R$ is heterogeneously distributed in the primate brain, with the highest concentration in the 


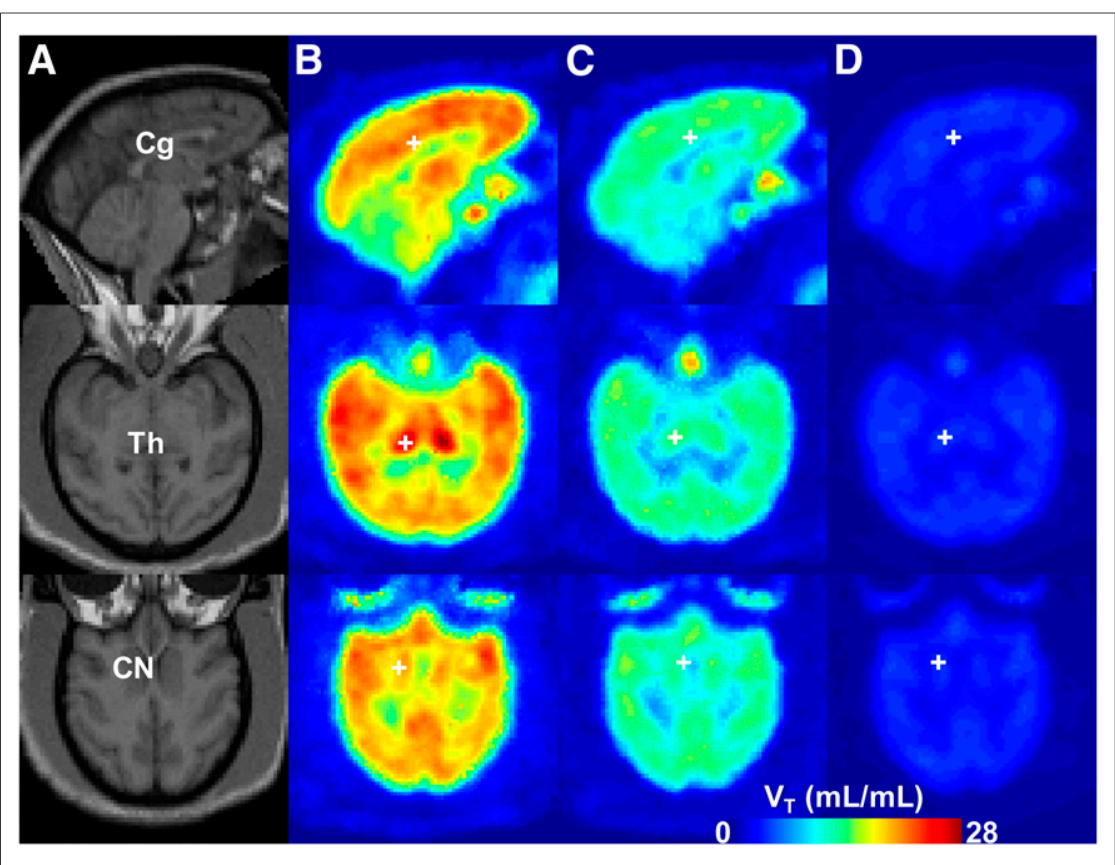

FIGURE 7. Sagittal (top) and transaxial (middle and bottom) views of $V_{T}$ images of ${ }^{18} \mathrm{~F}-A S E M$ in same baboon for baseline PET scan (B) and after administration of $0.5 \mathrm{mg} / \mathrm{kg}(\mathrm{C})$ and $5 \mathrm{mg} / \mathrm{kg}$ (D) of SSR180711, a selective a7-nAChR partial agonist. MR images (A) indicate locations of selected brain structures including cingulate cortex $(\mathrm{Cg})$, thalamus $(\mathrm{Th})$, and caudate nucleus $(\mathrm{CN})$, which are indicated by + in $\mathrm{V}_{\mathrm{T}}$ images $(\mathrm{D})$. $\mathrm{V}_{\mathrm{T}}$ images were displayed using same minimum and maximum values for all scanning conditions. These data demonstrate dose-dependent blockade of ${ }^{18} \mathrm{~F}$-ASEM in baboon brain and provide evidence that ${ }^{18} \mathrm{~F}$-ASEM is specific and mediated by $a 7-n A C h R$. Images also suggest that there is no reference region devoid of a7nAChRs.

thalamus, putamen, several cortical regions, and hippocampus (2932). The observed PET regional distribution patterns of ${ }^{18} \mathrm{~F}-\mathrm{ASEM}$ in the baboon brain (thalamus $>$ putamen, cortex, hippocampus $>$ caudate nucleus, globus pallidus $>$ corpus callosum) are consistent with in vitro data in rhesus and cynomolgus macaque monkeys $(29,30,32)$. The existing quantitative nonhuman primate data describing the brain distribution of $\alpha 7-\mathrm{nAChR}$ using in vitro autoradiography are detailed only for subcortical regions but limited for cortical regions or semiquantitative $(29,30,32)$. The PET ${ }^{18} \mathrm{~F}$-ASEM baboon experiments demonstrated that the lowest $\alpha 7-n A C h R$ uptake, albeit still considerable, was in the cerebellum. The cerebellum was not assessed in the previous monkey autoradiography studies $(29,30,32)$. It is noteworthy that the uptake of radioactivity in the baboon skull was low, suggesting little metabolism of ${ }^{18} \mathrm{~F}$-ASEM to ${ }^{18} \mathrm{~F}$-fluoride that can confound PET studies with ${ }^{18} \mathrm{~F}$-labeled agents.

The dose-dependent blockade of ${ }^{18} \mathrm{~F}$-ASEM with the selective $\alpha 7$ nAChR partial agonist SSR180711 (Figs. 6 and 7) demonstrated that the binding of the radioligand in the baboon brain was specific (up to $80 \%-90 \%$ ) and mediated by $\alpha 7-\mathrm{nAChR}$. The level of specific binding of ${ }^{18} \mathrm{~F}$-ASEM is well above the conventional minimum of the required specific binding value ( $\geq 50 \%$ ) for a clinically viable PET radioligand. ${ }^{18} \mathrm{~F}$-ASEM is suitable for quantitative analysis, and its $\mathrm{BP}_{\mathrm{ND}}$ values (3.9-6.6) in the baboon brain are rather high. For comparison, the $\mathrm{BP}_{\mathrm{ND}}$ values of all previously published $\alpha 7-\mathrm{nAChR}$ radioligands did not exceed $1(9-11,17)$. This high specific binding of ${ }^{18} \mathrm{~F}$-ASEM in combination with high brain uptake and $\mathrm{V}_{\mathrm{T}}$ values, reversible brain kinetics, and absence of active metabolites make this radioligand an excellent candidate for further translation to human PET imaging of $\alpha 7$-nAChRs.

\section{CONCLUSION}

We have developed a new specific $\alpha 7$ nAChR ligand, ${ }^{18} \mathrm{~F}-\mathrm{ASEM}$, that demonstrates suitable properties for imaging this important CNS target with PET in mice and baboons. Unlike its predecessors, ${ }^{18} \mathrm{~F}$ ASEM has proved to be amenable to quantitative analysis with a useful degree of binding specificity (up to $80 \%-90 \%$ ) and high $\mathrm{BP}_{\mathrm{ND}}$ values of 3.9-6.6 in the $\alpha 7$ $\mathrm{nAChR}$-rich brain regions as demonstrated by in vivo receptor blockade studies in baboons.

The brain uptake of ${ }^{18} \mathrm{~F}$-ASEM in an established rodent model of schizophrenia, DISC1 mutant mice, reflects reduced $\alpha 7$ nAChR binding, which has been shown previously only in postmortem human studies, lending further support to this model and suggesting the high utility of ${ }^{18} \mathrm{~F}-\mathrm{ASEM}$ for studying diseases of nicotinic transmission.

The ${ }^{18}$ F-ASEM radioligand holds considerable promise for human studies for understanding the role of $\alpha 7-n A C h R s$ in CNS disorders and will aid $\alpha 7-\mathrm{nAChR}$-targeted drug development. Experiments in relevant human populations are being vigorously pursued.

\section{DISCLOSURE}

The costs of publication of this article were defrayed in part by the payment of page charges. Therefore, and solely to indicate this fact, this article is hereby marked "advertisement" in accordance with 18 USC section 1734. This research was supported by NIH grants MH079017 and AG037298 and, in part, by the Division of Nuclear Medicine of Johns Hopkins University School of Medicine. No other potential conflict of interest relevant to this article was reported.

\section{ACKNOWLEDGMENTS}

We thank Dr. Richard Wahl for fruitful discussions. We also thank Drs. Weiguo Ye, Asifa Zaidi, and Jennifer Coughlin for injecting baboons with ${ }^{18} \mathrm{~F}$-ASEM. We are grateful to Paige Finley, Heather Valentine, Gilbert Green, and Chunxia Yang for their valuable help with baboon and mouse experiments; David J. Clough and Karen Edmonds for PET scanner operation; and Alimamy Kargbo for HPLC analysis of radiometabolites. We are thankful to Julia Buchanan for editorial help.

\section{REFERENCES}

1. Albuquerque EX, Pereira EF, Alkondon M, Rogers SW. Mammalian nicotinic acetylcholine receptors: from structure to function. Physiol Rev. 2009;89:73-120.

2. Lukas RJ, Changeux JP, Le Novere N, et al. International Union of Pharmacology. XX: current status of the nomenclature for nicotinic acetylcholine receptors and their subunits. Pharmacol Rev. 1999;51:397-401.

3. Woodruff-Pak DS, Gould TJ. Neuronal nicotinic acetylcholine receptors: involvement in Alzheimer's disease and schizophrenia. Behav Cogn Neurosci Rev. 2002;1:5-20.

4. D'hoedt D, Bertrand D. Nicotinic acetylcholine receptors: an overview on drug discovery. Expert Opin Ther Targets. 2009;13:395-411. 
5. Kelso ML, Oestreich JH. Traumatic brain injury: central and peripheral role of alpha7 nicotinic acetylcholine receptors. Curr Drug Targets. 2012;13:631-636.

6. Auld DS, Kornecook TJ, Bastianetto S, Quirion R. Alzheimer's disease and the basal forebrain cholinergic system: relations to beta-amyloid peptides, cognition, and treatment strategies. Prog Neurobiol. 2002;68:209-245.

7. Aubert I, Araujo DM, Cecyre D, Robitaille Y, Gauthier S, Quirion R. Comparative alterations of nicotinic and muscarinic binding sites in Alzheimer's and Parkinson's diseases. J Neurochem. 1992;58:529-541.

8. Thomsen MS, Hansen HH, Timmerman DB, Mikkelsen JD. Cognitive improvement by activation of alpha7 nicotinic acetylcholine receptors: from animal models to human pathophysiology. Curr Pharm Des. 2010;16:323-343.

9. Horti AG, Villemagne VL. The quest for Eldorado: development of radioligands for in vivo imaging of nicotinic acetylcholine receptors in human brain. Curr Pharm Des. 2006;12:3877-3900.

10. Toyohara J, Wu J, Hashimoto K. Recent development of radioligands for imaging alpha7 nicotinic acetylcholine receptors in the brain. Curr Top Med Chem. 2010;10:1544-1557.

11. Brust P, Deuther-Conrad W. Molecular imaging of alpha7 nicotinic acetylcholine receptors in vivo: current status and perspectives. In: Bright P, ed. Neuroimaging: Clinical Applications. Rijeka, Croatia: InTech; 2012:533-558.

12. Gao Y, Ravert HT, Valentine H, et al. 5-(5-(6-[ $\left[{ }^{11} \mathrm{C}\right]$ methyl-3,6-diazabicyclo [3.2.0] heptan-3-yl)pyridin-2-yl)- ${ }^{1} \mathrm{H}$-indole as a potential PET radioligand for imaging cerebral alpha7-nAChR in mice. Bioorg Med Chem. 2012;20:36983702 .

13. Horti AG, Ravert HT, Gao Y, et al. Synthesis and evaluation of new radioligands $\left[{ }^{11} \mathrm{C}\right] \mathrm{A}-833834$ and $\left[{ }^{11} \mathrm{C}\right] \mathrm{A}-752274$ for positron-emission tomography of alpha7nicotinic acetylcholine receptors. Nucl Med Biol. 2013;40:395-402.

14. Pomper MG, Phillips E, Fan H, et al. Synthesis and biodistribution of radiolabeled alpha 7 nicotinic acetylcholine receptor ligands. J Nucl Med. 2005;46:326-334.

15. Toyohara J, Sakata M, Wu J, et al. Preclinical and the first clinical studies on $\left[{ }^{11} \mathrm{C}\right]$ CHIBA-1001 for mapping alpha7 nicotinic receptors by positron emission tomography. Ann Nucl Med. 2009;23:301-309.

16. Ding M, Ghanekar S, Elmore CS, et al. [ $\left.{ }^{3} \mathrm{H}\right]$ Chiba-1001 (methyl-SSR180711) has low in vitro binding affinity and poor in vivo selectivity to nicotinic alpha-7 receptor in rodent brain. Synapse. 2012;66:315-322.

17. Gao Y, Kellar KJ, Yasuda RP, et al. Derivatives of dibenzothiophene for PET imaging of a7-nicotinic acetylcholine receptors. J Med Chem. 2013;56:75747589.

18. Xiao Y, Abdrakhmanova GR, Baydyuk M, Hernandez S, Kellar KJ. Rat neuronal nicotinic acetylcholine receptors containing alpha7 subunit: pharmacological properties of ligand binding and function. Acta Pharmacol Sin. 2009;30: 842-850.
19. Pletnikov MV, Ayhan Y, Nikolskaia O, et al. Inducible expression of mutant human DISC1 in mice is associated with brain and behavioral abnormalities reminiscent of schizophrenia. Mol Psychiatry. 2008;13:173-186.

20. Kuwabara H, Wong DF, Gao Y, et al. PET Imaging of nicotinic acetylcholine receptors in baboons with ${ }^{18} \mathrm{~F}$-AZAN, a radioligand with improved brain kinetics. J Nucl Med. 2012;53:121-129.

21. Ashburner J, Friston KJ. High-dimensional image warping. In: Frackowiak R, Ashburner J, Penny WD, et al., eds. Human Brain Function. 2nd ed. San Diego, CA: Academic Press; 2004:673-694.

22. Ashburner J, Friston KJ. Rigid body registration. In: Frackowiak R, Ashburner J, Penny WD, et al., eds. Human Brain Function. 2nd ed. San Diego, CA: Academic Press; 2004:635-654.

23. Akaike H. A new look at statistical model identification. IEEE Trans Automat Contr. 1974; 19:716-722.

24. Logan J, Fowler JS, Volkow ND, et al. Graphical analysis of reversible radioligand binding from time-activity measurements applied to [N-11 C-methyl](-)-cocaine PET studies in human subjects. J Cereb Blood Flow Metab. 1990; 10:740-747.

25. Lassen NA, Bartenstein PA, Lammertsma AA, et al. Benzodiazepine receptor quantification in vivo in humans using $\left[{ }^{11} \mathrm{C}\right]$ flumazenil and PET: application of the steady-state principle. J Cereb Blood Flow Metab. 1995;15:152-165.

26. Biton B, Bergis OE, Galli F, et al. SSR180711, a novel selective alpha7 nicotinic receptor partial agonist: (1) binding and functional profile. Neuropsychopharmacology. 2007;32:1-16.

27. Schrimpf MR, Sippy KB, Briggs CA, et al. SAR of alpha7 nicotinic receptor agonists derived from tilorone: exploration of a novel nicotinic pharmacophore. Bioorg Med Chem Lett. 2012;22:1633-1638.

28. Decker MW, Meyer MD. Therapeutic potential of neuronal nicotinic acetylcholine receptor agonists as novel analgesics. Biochem Pharmacol. 1999;58:917-923.

29. Kulak JM, Schneider JS. Differences in alpha7 nicotinic acetylcholine receptor binding in motor symptomatic and asymptomatic MPTP-treated monkeys. Brain Res. 2004;999:193-202.

30. Kulak JM, Carroll FI, Schneider JS. [ ${ }^{125}$ I]iodomethyllycaconitine binds to alpha7 nicotinic acetylcholine receptors in monkey brain. Eur J Neurosci. 2006;23:26042610 .

31. Breese CR, Adams C, Logel J, et al. Comparison of the regional expression of nicotinic acetylcholine receptor alpha7 mRNA and $\left[{ }^{125} \mathrm{I}\right]$-alpha-bungarotoxin binding in human postmortem brain. J Comp Neurol. 1997;387:385-398.

32. Han ZY, Zoli M, Cardona A, Bourgeois JP, Changeux JP, Le Novere N. Localization of $\left[{ }^{3} \mathrm{H}\right]$ nicotine, $\left[{ }^{3} \mathrm{H}\right]$ cytisine, $\left[{ }^{3} \mathrm{H}\right]$ epibatidine, and $\left[{ }^{125} \mathrm{I}\right]$ alpha-bungarotoxin binding sites in the brain of Macaca mulatta. J Comp Neurol. 2003;461: 49-60. 